\title{
Introduktion til Pierre Bourdieu: "De tre former for teoretisk viden"
}

\author{
Staf Callewaert \\ Professor emeritus i pædagogik, Institut for medier, erkendelse og formidling, \\ Københavns Universitet \\ staf.callewaert@gmail.com
}

Som en introduktion til Pierre Bourdieus lange og svære artikel om tre former for (videnskabelig) kundskab (Bourdieu 1973), skal her fremhæves de væsentlige aspekter. Målsætningen er helt præcist at bestemme, hvor Bourdieu tilføjer en urgammel diskussion noget nyt.

Bourdieu hævder, at der findes tre former for videnskabelig kundskab omkring menneskenes sociale praktikker: Den fænomenologiske, den objektivistiske og den praxeologiske. Bourdieu hævder, at den fænomenologiske og den objektivistiske hver for sig er utilstrækkelige og derfor fejlagtige. Derimod kombinerer den praxeologiske videnskabsform en fænomenologisk dimension og en objektivistisk dimension med en praktisk dimension og er på den måde en mere fuldstændig og rigtig kundskabsform.

Fænomenologisk teori rekonstruerer begrebsligt eksplicit agenternes primære erfaringer af deres sociale forhold og praktikker. Agenternes umiddelbare erfaringer med deres egne forhold og praktikker er ikke refleksiv. Agenterne erfarer deres forhold og praktikker som naturlige og selvfølgelige. Den erfaring udelukker per definition, at agenten stiller spørgsmål angående denne erfarings mulighedsbetingelser: Hvorfor udformer min erfaring med min praktik sig på netop denne måde? Hvorfor forekommer min praktik sådan for mig?

Den fænomenologiske teori er refleksiv. Men eftersom den opfatter sig selv som intet andet end en eksplicitering af den primære erfaring, så kan den heller ikke stille spørgsmål om erfaringens mulighedsbetingelser. Teorien har i forvejen lukket sig inde i den primære erfarings cirkel.

Bagved Bourdieus analyse ligger antagelsen om, at de sociale forhold/praktikker har objektive egenskaber, som ikke opfattes af agenternes primære erfaringer. En lærer eller sygeplejerske har en umiddelbar erfaring af sin egen praktik, som ikke dækker alle aspekter af denne praktik. Som vi skal se, beror dette i henhold til den praxeologiske teori ikke på, at agenten savner skarpsindighed.

Teksten udgør et yderst sparsomt redigeret uddrag (s. 13-19) af Staf Callewaerts "Indledning" i Callewaert et al. (red.) (1994-2008). Antologien har udkommet i fem oplag; dels fra Akademisk Forlag (1994, 1995, 1997 og 1998), dels fra forlaget Frydenlund (2008). Forfatteren takker Frydenlund for tilladelsen til at bringe teksten her.

Publisert: 01.01.2019

Praxeologi - Et kritisk refleksivt blikk på sosiale praktikker @2019 Staf Callewaert

Dette er en open access-artikkel distribuert under vilkårene i lisensen Creative Commons Navngivelse (CC-BY 4.0) DOI: http://dx.doi.org/10.15845/praxeologi.v1i0.2595 
Anledningen til fejlen ligger ikke i blikket, men i det, som blikket skal fange, og som gemmer sig for blikket.

Objektivistisk teori er ikke primært interesseret i agenternes egne erfaringer og oplevelser. Den konstrueres af den udenforstående, som ser på praktikken udefra. Objektivistisk teori er primært interesseret $\mathrm{i}$, at sætte disse praktikker i relation til de betingelser, som ser ud til at kunne forklare dem, selv om agenterne eventuelt ikke er vidende om disse bagvedliggende faktorer og altså ikke bevidste om praktikkernes fuldstændige indhold. En objektivistisk teori konstrueres altså ved at bryde med agenternes umiddelbare erfaring som udgangspunkt og ved allerede fra begyndelsen at spørge efter praktikkernes mulighedsbetingelser, dvs. faktorer, som gør, at de ser ud, som de ser ud.

Men hvilke objektive forhold hos disse praktikker $g \varnothing r$, at de i agenternes umiddelbare erfaring ikke fremtræder som det, de er? Svaret er, at disse praktikker på en gang er menneskelige handlinger, som har behov for en legitimation, og er betingede af objektive forhold, som strukturerer disse handlinger bagom ryggen på agenterne. Og der findes en modsætning mellem det, som kan legitimere handlingerne, og det, som strukturerer dem. Denne modsætning leder til, at agenten fortrænger de strukturerende faktorer i samme øjeblik, den erkender de legitime grunde.

I sin umiddelbare erfaring med sin daglige praktik kan sygeplejersken forstå sin praktik som en form for omsorg, hvilket medfører, at hun overser, at praktikken (også) styres af den medicinske behandlingslogik, af lønarbejdets logik, af magtrelationer mellem læger, sygeplejersker og patienter osv. Naturligvis behøver sygeplejersken ikke at være helt uvidende om disse aspekter, men det flytter ikke sygeplejerskens grundlæggende opfattelse af, at det hun arbejder med er omsorg.

Det vil sige: Den primære erfaring er en helt rigtig afspejling af agentens illusoriske forhold til sin egen praktik mere end en objektiv beskrivelse af, hvad denne praktik indebærer. Og det forholder sig sådan, ikke fordi agenten savner skarpsindighed, bedrager sig selv eller bliver bedraget af ideologer. Det forholder sig sådan, fordi sociale forhold altid og overalt, omend i forskellig grad, sætter sig igennem uden at bekende kulør fuldt ud. Dette beror på at sociale forhold altid også omfatter et aspekt af vilkårlig magtudøvelse samtidig med, at de forudsætter en legitimering.

Praxeologisk teori, Bourdieus forslag til en teori, som den bør være, er et fors $\varnothing g$ på at bevare det rigtige i den fænomenologiske og i den objektivistiske teori, et fors $\varnothing \mathrm{g}$ på at komplettere dem med en tredje dimension, og et fors $\emptyset \mathrm{g}$ på at kombinere disse tre dimensioner på en speciel måde.

Den praxeologiske teori må også begrebsligt eksplicitere agenternes primære erfaring af deres egen praktik: Dette er et aspekt af den udenforstående forskers arbejde med agenternes oplevelser.

Den praxeologiske teori må dog i anden omgang bryde med denne indforståede erfaring og rekonstruere det netværk af bagvedliggende faktorer, som strukturerer praktikkerne. I denne fase kan man få hjælp af det arbejde, som den objektivistiske teori har præsteret. Disse aspekter af praktikken kan man ikke hente fra den primære erfaring og den fænomenologiske eksplicitering, som har udelukket dem.

Men den praxeologiske teori må desuden lægge en tredje dimension til. Og den kræver, at man nu også bryder med den objektivistiske teoris indfaldsvinkel, som er den udenforstående objektiverende forskers indfaldsvinkel. For den objektiverende forsker optræder praktikken bare i tredje person og som et fuldbyrdet faktum, som ligger der til beskuelse: Det, som agenten har gjort $\mathrm{i}$ overensstemmelse med sine baggrundsfaktorer, ligger som fakta for det udenforstående blik. Men praktikker eksisterer jo i virkeligheden, ikke bare som fakta for et blik, der beskuer dem udefra. De eksisterer også og frem for alt som noget, som en agent har foran sig i handlingens øjeblik, som udelukker den objektiverende refleksion. Det er noget, som her og nu må gøres, et forløb som skal fuldbyrdes, og ikke en sammenhæng som er fuldbyrdet. Alle praktikkens sider er da ikke nærværende samtidig i form af et kort, en kalender, en model eller en tabel med variabler. De optræder som en sekvens. Det, som foresvæver den handlende, er ikke den sammenhængende forklaring, men den strategiske fremgangsmåde for at gennemføre noget i en unik situation. 
Med andre ord: Den bevidsthed, som vejleder praktikeren i praktikken, er den praktiske sans. Men, det helt afgørende er, at denne praktiske sans adskiller sig fra såvel den primære erfaring/den spontane oplevelse som fra den objektivistiske forklaring. Dette er det nye ved Bourdieus teori, hvilket kræver endnu en udredning.

Først kan vi præcisere dette negativt i de to angivne retninger:

Den praktiske sans adskiller sig fra den primære erfaring. Vi har set, at den primære erfaring ikke udtrykker praktikken under udførslen, men praktikerens illusoriske omend nødtvungne forhold til sin praktik. Derfor kan det heller ikke være den spontane oplevelse, som styrer praktikken.

Ved at bryde med den spontane oplevelse som udgangspunkt for teorikonstruktionen, har den praxeologiske teori taget et privilegium fra agenterne, nemlig, at de er de eneste, som er kompetente til at udtale sig om deres praktik, eftersom de er de eneste, som udfører den. I stedet søger den praxeologiske teori at påvise, at agenterne med en vis nødvendighed fortrænger væsentlige aspekter af deres praktik.

Vi har også set, at der findes bagvedliggende faktorer, som er med til at styre praktikken. Det er dette aspekt, som den objektivistiske teori har indfanget. Den objektivistiske teori tilskriver forskeren det privilegium, som den tager fra praktikeren. Forskeren rekonstruerer de fortrængte aspekter af praktikken. Forskerens teori giver et sandere billede af praktikken end praktikerens spontane umiddelbare oplevelser.

Men på det plan kræver den praxeologiske teori, at vi nu også bryder med forskerens objektivisme og tager objektivitetens privilegium fra ham. Forskerens objektive blik har nemlig også forvrænget billedet af hvad, det i virkeligheden handler om. Forskeren tror, at de kortlagte faktorer i den objektivistiske teori styrer praktikerens handlen. Men det gør de lige så lidt, som agentens spontane oplevelser gør det. Den bevidsthed, som på en styrende måde ledsager praktikerens praktik, er ikke forskerens kort, kalender, model eller tabel, men er en praktisk tilstand. Den praktiske sans er ikke tillempet teori, lige så lidt som det er sund fornuft. Bonden, som går ud om morgenen til sin olivenlund på den anden side af bjerget, holder naturligvis ikke kortet i sin hånd, men han har heller ikke et intuitivt kort i hovedet: Det er bogstavelig talt hans fødder, som ved, hvad vej de skal gå.

Men hvad er da den praktiske sans i positiv forstand? Den praktiske sans er i deskriptive termer det, som habitus er i den praxeologiske teorikonstruktion. Det går ud på, at den praktiske omgang med de objektive livsvilkår og handlemuligheder lagrer sig i form af subjektive dispositioner i agenten. De fungerer som tavse, praktiske orienteringsskemaer, som orienterer iagttagelse, tænken, vurdering og handlen. Det er via den internalisering af de eksterne betingelser, at de bagvedliggende faktorer har en styrende effekt på praktikken. Og den praktiske sans er mere adækvat og træfsikker end de spontane umiddelbare oplevelser, som allerede også har karakter af nødtvungen efterrationalisering. Deraf kommer det, at praktikerens praktik er bedre afstemt med situationen, end praktikeren selv ved eller kan gøre rede for, i det mindste så længe situationen i grove træk er den samme som den, der er ophav til dispositionen.

Den praxeologiske teori fastholder altså, at det er nødvendigt at bryde med både den spontane oplevelse og den objektivistiske teori, som udgangspunkt for en teori om praktikken. Hverken den spontane oplevelse eller den objektivistiske teori kan tilbyde et korrekt udgangspunkt for det teoretiske konstruktionsarbejde.

Den praxeologiske teori gør krav på at medreflektere både den spontane oplevelse og den teoretiske forklaring og de mulighedsbetingelser, som de begge på hver deres måde fortrænger.

Da artiklen om de tre former for kundskab blev skrevet, var strukturalismen et modefænomen. Derfor tager Bourdieu den strukturalistiske lingvistik op som et eksempel på objektivistiske teorier. Det kan føles lidt mærkeligt, når man forventer sig at Bourdieu som sociolog skulle tage eksempler op fra sociologien eller fra antropologien. Men det er ikke så mærkeligt, når man tænker på, at hans 
sociologi i meget stor udstrækning har interesseret sig for den symbolske side af sociale forhold. Det vil sige for sociale forhold, som sammenholdes af deres betydning, forholdet mellem indhold og form. Sociale forhold eksisterer i kraft af, at de har en mening for deltagerne.

Ferdinand de Saussure opretter lingvistikken som en specifik videnskab netop ved at arbejde med et objektivistisk kundskabssyn. Saussure ser bort fra, at nogen siger noget til nogen om noget med hensigt på noget bestemt. Han ser bort fra talen, for kun at studere sproget, det medium, som agenterne anvender. Sproget er da en objektiv struktur, og sprogkompetencen er den ubevidste, indlærte evne til at indkode og afkode, som afsenderen og modtageren deler med hinanden. Et sprog er en kode. Koden er totalt uafhængig af de talendes bevidsthed eller vilje, af de talendes umiddelbare forståelse af den betydning, som kommunikeres, eller hvorvidt koden anvendes praktisk i talen. Når jeg umiddelbart forstår, hvad en anden siger på vores fælles modersmål, er jeg ikke klar over, at dette i virkeligheden beror på, at vi begge anvender den underliggende kode, som er en ubevidst kompetence uafhængig af vor praktik.

Den objektivistiske teori om sproget fornægter altså ikke, at den talende har en umiddelbar oplevelse af at forstå, hvad den anden siger. Den objektivistiske teori rekonstruerer mulighedsbetingelserne for denne oplevelse. Den forudsætter eksistensen af en objektiv fælles kode uafhængig af denne oplevelse og en modsvarende kompetence i form af en ubevidst indlært disposition. Forud for sådan en kode findes der heller ingen umiddelbar forståelse.

Fænomenologisk sprogteori derimod interesserer sig for den umiddelbare oplevelse af gensidig forståelse i en samtalesituation. Men selv Edmund Husserl var bevidst om, at en sådan fænomenologisk analyse forudsætter, at man også klarlægger, under hvilke betingelser den umiddelbare forståelse som objekt for analysen i det hele taget foreligger.

Men når man taler, når man praktiserer sproget, er man ikke bevidst om disse betingelser for at kunne tale. Det, som dog er kendetegnende for den strukturalistiske rekonstruktion af det praktiserede sprog og dets betingelser, er, at man bare ser på sproget som en kode. Koden er det sprog, der foreligger som et fuldbyrdet faktum, og ikke det sprog, som man er i gang med at tale, som endnu ikke findes og er under udformning.

Det er for alle mennesker en illusion at tro, at koden findes i forvejen, og at talen ikke er andet end anvendelse af koden. Det er koden, som forklarer talen, ikke talen som forklarer koden. Det gør, at man frasiger sig muligheden for at se andre betingelser, der er lige så vigtige, og som tilmed får en til at indse, at koden egentlig ikke er en kode.

Samtalesituationen er nemlig ikke bare en kommunikativ situation. Den er også en situation, hvor symbolske magtrelationer udfolder sig og spiller sammen med politiske og $\varnothing$ konomiske magtrelationer. Alle disse aspekter savnes i den strukturalistiske sprogteori.

Men da kunne man tænke sig, at man kunne kombinere den strukturalistiske sprogteori med en strukturalistisk kulturteori og samfundsteori og på denne måde genoprette helheden. Det er faktisk det, som de kulturalistiske og funktionalistiske kultur- og samfundsteorier har gjort. De fremstiller kulturel praktik og social praktik som anvendelse af koder.

Det vil sige: Vi har en lang række af objektivistiske teorier, som forklarer sprogadfærd, kulturel adfærd, social adfærd på en af følgende måder:

1. Ud fra en naiv, realistisk måde: Sprog, kultur og samfund findes på samme måde som bjerge, dale og borde

2. Ud fra en strukturalistisk måde: Sprog, kultur og samfund er koder, som kommer til anvendelse, men ikke er umiddelbart synlige og må rekonstrueres ud fra den observerede adfærd 
3. Ud fra en idealistisk måde: Sprog, kultur og samfund angiver normer, som man må lyde

4. Ud fra en objektivistisk, videnskabelig måde: Sproglig, kulturel eller social adfærd følger nogle regler:

a. Reglerne konstrueres af forskeren ud fra de observerede regelmæssigheder. Agenterne skal følge samme regler. Forskerens forklaring findes hos agenterne i eksplicit form og optræder der som styrende

b. Disse regler findes ikke hos agenterne som styrende principper i explicit form, som agenterne bevidst følger, men som et princip, en kode, som styrer agenterne ubevidst

Alle disse forklaringer er fejlagtige. Selv den sidste (4.b.), som umiddelbart kan virke som om den er identisk med Bourdieus habitus-teori. Det, som Bourdieu vil sige med sin habitus-teori, er præcis det modsatte. Det, Bourdieu hævder, er den stærkest tænkbare tese, at det end ikke er et implicit regelsystem, som styrer. Det, der styrer, er en praktisk sans, der opererer som en opfindsom og uforudsigelig improvisation. De observerbare regelmæssigheder, som forskeren rekonstruerer som et regelsystem, opstår ikke fordi en kode tillempes, men fordi overensstemmende betingelser mødes med overensstemmende strategier. Alle regelsystemer er ikke bare konstruktioner, men efterrationaliseringer, som mangler det væsentlige: Orkesteret spiller uden dirigent og uden partitur, men $g \varnothing r$ det som om, der fandtes en dirigent og et partitur.

\section{Referencer}

Bourdieu, P. (1973). The three forms of theoretical knowledge. Social Science Information 12(1), s. 53-80.

Bourdieu, P. (1994). De tre former for teoretisk viden. I S. Callewaert, M. Munk, M. Nørholm \& K.A. Petersen (red.), Pierre Bourdieu. Centrale tekster inden for sociologi og kulturteori (s. 70-108). København: Akademisk Forlag/Frydenlund.

Callewaert, S. (1994). Indledning. I S. Callewaert, M. Munk, M. Nørholm \& K.A. Petersen (red.), Pierre Bourdieu. Centrale tekster inden for sociologi og kulturteori (s. 9-19). København: Akademisk Forlag/Frydenlund. 